\title{
Effect of Substitution of Normal Weight Coarse Aggregate with Oil-Palm-Boiler Clinker on Properties of Concrete
}

\author{
(Kesan Penggantian Agregat Kasar Berat Biasa dengan Klinker Dandang Kelapa-Sawit ke atas Sifat Konkrit)
}

\author{
LeE Jin Chai, Payam Shafigh*, Hilmi Mahmud \& Muhammad Aslam
}

\begin{abstract}
Oil-palm-boiler clinker $(O P B C)$ is an agricultural solid waste sourced from the palm oil industry in tropical regions. This study investigates the use of OPBC as coarse aggregate instead of conventional coarse aggregates to produce a greener concrete, which will help in implementing sustainable construction practices by reducing the usage of raw materials. For this purpose, normal weight coarse aggregates was substituted with dry OPBC aggregates up to $75 \%$ (by volume) in a high strength normal weight concrete. The effectiveness of this substitution on the properties of the concrete such as workability, density, compressive strength, splitting tensile strength and modulus of elasticity was studied.The slump test results showed that using $O P B C$ in dry condition reduced the workability of the concrete and therefore can be used up to $50 \%$ of the total volume of coarse aggregate. Concrete containing $50 \%$ OPBC can be considered as semi-lightweight concrete with high strength. Using OPBC in concrete reduced the splitting tensile strength and modulus of elasticity, however, the reduction was not significant.
\end{abstract}

Keywords: Lightweight aggregate; lightweight aggregate concrete; mechanical properties; oil-palm-boiler clinker

\section{ABSTRAK}

Klinker dandang kelapa-sawit (OPBC) adalah sisa pepejal pertanian yang diperoleh daripada industri kelapa sawit di kawasan tropika. Penyelidikan ini mengkaji penggunaan OPBC sebagai agregat kasar dan bukan sebagai agregat kasar konvensional untuk penghasilan konkrit lebih hijau yang akan membantu dalam melaksanakan amalan pembinaan mampan dengan mengurangkan penggunaan bahan mentah. Bagi tujuan ini, berat normal agregat kasar digantikan dengan agregat OPBC kering sehingga 75\% (isi padu) dalam konkrit kekuatan tinggi berat normal. Keberkesanan penggantian ini pada sifat konkrit kebolehkerjaan, ketumpatan, kekuatan mampatan, kekuatan pemecahbelahan tegangan dan modulus keanjalan turut dikaji. Keputusan ujian nendat menunjukkan bahawa penggunaan OPBC dalam keadaan kering mengurangkan kebolehkerjaan konkrit dan oleh yang demikian, OPBC boleh digunakan sehingga 50\% daripada jumlah bilangan agregat kasar. Konkrit yang mengandungi 50\% OPBC boleh dianggap sebagai konkrit yang separa ringan dengan kekuatan tinggi. Penggunaan OPBC dalam konkrit mengurangkan kekuatan pemecahbelahan tegangan dan modulus keanjalan, walau bagaimanapun, pengurangan adalah tidak ketara.

Kata kunci: Agregat ringan; agregat ringan konkrit; klinker dandang kelapa sawit; sifat mekanik

\section{INTRODUCTION}

Construction industry in Malaysia has been continuously contributing between $3 \%$ and $5 \%$ of the national Gross Domestic Product (GDP) over the last twenty years (CIDB 2000). The construction industry is also an industry that has a considerable negative impact on the environment including soil erosion, flooding, depletion of natural resources and the use of construction materials affecting human health (CIDB 2007). Wong (2012) reported that the main construction material involved in the construction industry is concrete, of which 25 billion tons is generated annually worldwide to cater to the high demand. Chin (2005) showed that recently, many industries were encouraged to be aware of the crucial need to utilise natural resources in a sustainable manner and building developers were warned to ensure that the environment is not sacrificed in favour of economic development in Malaysia. Concrete is cast using natural resources harvested from the environment. The bulk harvesting process has a negative impact on the environment and the natural resources dramatically reduce annually. Therefore, the usage of industrial wastes and recycled materials should be promoted to reduce the negative effects on the environment and the pollution generated by human activities (Mannan \& Ganapathy 2002).

Malaysia currently produces $51 \%$ of world palm oil production and $62 \%$ of world exports (Omain et al. 2010). Wahid (2005) reported that Sabah has the largest area of oil palm plantation in Malaysia with about 1.2 million hectares. Around $80 \%$ of processed fresh fruit bunches of palm oil tree is categorized as solid waste (CEBAR 2006). This solid waste produces 2.6 million tons of oil 
palm shell in the milling process every year (Mannan \& Ganapathy 2004). In general, electricity for operation of oil palm mill is generated through producing steam from solid fuel by burning fibres and shells of the oil palm trees. Oil-palm-boiler clinker (OPBC) is a part of this burnt solid waste. Consequently, this has resulted in a disposal problem in Malaysia. The waste is usually dumped fully in the plantation area or used to cover potholes in the road pavement (Kanadasan \& Abdul 2015). In view of sustainability, researchers have focused on investigating the concept of the utilization of OPBC as a renewable resource to replace the natural stone aggregate.

Apart from using OPBC as a landfill material, it can be compressed to form an aggregate to be used in lightweight aggregate concrete (LWAC). An aggregate is classified as lightweight aggregate with a specific gravity of less than 2.2 and a particle oven dry density of between 800 and $2000 \mathrm{~kg} / \mathrm{m}^{3}$ or a dry loose bulk density of less than $1200 \mathrm{~kg} / \mathrm{m}^{3}$ (BSI 1992). The incorporation of OPBC for the manufacturing of lightweight concrete has achieved good results. Not only lightweight but also high strength concrete having a compressive strength of 60 to $70 \mathrm{MPa}$ which can be produced by self-compacting OPBC lightweight concrete (Kanadasan \& Abdul 2015). A highly workable slump value of $125 \mathrm{~mm}$ has been produced by adding fly ash resulting in OPBC concrete with a compressive strength of $42 \mathrm{MPa}$ (Ahmad \& Mohd 2007). The incorporation of OPBC in lightweight concrete is capable of producing concrete with the lowest density of $1769.2 \mathrm{~kg} / \mathrm{m}^{3}$ (Mohammed et al. 2011). Furthermore, by using OPBC as coarse and fine aggregate in the concrete to produce a pre-stressed concrete beam, the 28-day compressive strength was able to achieve up to 44.4 MPa (Omar \& Mohamed 2002).

The aim of this study was to investigate the effectiveness of substitution of normal coarse aggregate with OPBC on some engineering properties of concrete. For this purpose, normal coarse aggregate was substituted with $\mathrm{OPBC}$ in a high strength concrete. Fresh and hardened properties of concrete such as workability, density, compressive strength, splitting tensile strength and modulus of elasticity were studied.

\section{EXPERIMENTAL DETAILS}

\section{MATERIALS AND PROPERTIES}

Ordinary Portland cement conforming to MS 522 with a specific gravity of 3.14 and surface area of $1.89 \mathrm{~m}^{2} / \mathrm{g}$ was used as a binder. Local mining sand was used as fine aggregate. OPBC was obtained from a local crude palm oil mill. The OPBC was washed and crushed into a maximum nominal size of $9.5 \mathrm{~mm}$. The OPBC was used as partial replacement of normal weight coarse aggregate. All aggregates were used in dry condition in the concrete mixtures. In addition, Sika Viscocrete-2199, a superplasticizer, was used in the mixtures. The physical properties of the aggregates are shown in Table 1.

\section{PROPORTIONS}

In order to investigate the effectiveness of substituting normal weight coarse aggregate with OPBC on the engineering properties of high strength concrete, a grade 70 high strength concrete with high workability was designed as the control mix. In this mix, normal weight coarse aggregate (granite) was substituted with OPBC from 0 to $75 \%$ by volume in increments of $12.5 \%$. Therefore, all the mixes have the same mix proportions while containing different volumes of coarse aggregate. The mix proportions of all mixes are shown in Table 2.

\section{TEST METHOD}

Casting materials (cement as binder, crushed granite and OPBC as coarse aggregate, sand as fine aggregate, water and superplasticizer) were well prepared. All aggregates were placed into the mixer for $2 \mathrm{~min}$. Then, cement was

TABLE 1. Physical properties of the aggregates

\begin{tabular}{cccc}
\hline \multicolumn{1}{c}{ Physical property } & OPBC & Crushed granite & Local mining sand \\
\hline Specific gravity & 1.9 & 2.67 & 2.65 \\
Fineness & 5.02 & 5.04 & 2.65 \\
Bulk density (compacted) & $1409 \mathrm{~kg} / \mathrm{m}^{3}$ & $1453 \mathrm{~kg} / \mathrm{m}^{3}$ & $1615 \mathrm{~kg} / \mathrm{m}^{3}$ \\
Water absorption (30 min) $\%$ & $2.31 \%$ & $0.53 \%$ & $1.12 \%$ \\
Water absorption (24 h) $\%$ & $4.11 \%$ & $0.72 \%$ & $1.21 \%$ \\
\hline Grading & & & \\
Sieve size $(\mathrm{mm})$ & \multicolumn{3}{c}{ Cumulative $\%$ by weight passing } \\
\hline 19.1 & 100.0 & & 100.0 \\
9.5 & 100.0 & 100.0 & 100.0 \\
4.75 & 92.3 & 94.18 & 100.0 \\
2.36 & 5.65 & 2.1 & 86.2 \\
1.18 & 0.0 & 0.0 & 67.0 \\
0.6 & 0.0 & 0.0 & 50.2 \\
0.3 & 0.0 & 0.0 & 25.7 \\
0.15 & 0.0 & 0.0 & 6.1 \\
\hline
\end{tabular}


TABLE 2. Mix proportions $\left(\mathrm{kg} / \mathrm{m}^{3}\right)$

\begin{tabular}{|c|c|c|c|c|c|c|c|}
\hline \multirow{2}{*}{$\begin{array}{l}\text { Mix } \\
\text { No }\end{array}$} & \multirow{2}{*}{$\begin{array}{l}\text { Cement } \\
\left(\mathrm{kg} / \mathrm{m}^{3}\right)\end{array}$} & \multirow{2}{*}{$\begin{array}{l}\text { Water } \\
\left(\mathrm{kg} / \mathrm{m}^{3}\right)\end{array}$} & \multirow{2}{*}{$\begin{array}{c}\mathrm{Sp} \\
\left(\mathrm{kg} / \mathrm{m}^{3}\right)\end{array}$} & \multirow{2}{*}{$\begin{array}{l}\text { Fine aggregate } \\
\qquad\left(\mathrm{kg} / \mathrm{m}^{3}\right)\end{array}$} & \multicolumn{3}{|c|}{ Coarse aggregate $\left(\mathrm{kg} / \mathrm{m}^{3}\right)$} \\
\hline & & & & & Granite & OPBC & OPBC/Total coarse ratio \\
\hline M & 500 & 170 & 5 & 760 & 910 & 0 & 0 \\
\hline M12.5 & 500 & 170 & 5 & 760 & 796 & 81 & $12.5 \%$ \\
\hline M25 & 500 & 170 & 5 & 760 & 683 & 162 & $25 \%$ \\
\hline M37.5 & 500 & 170 & 5 & 760 & 569 & 243 & $37.5 \%$ \\
\hline M50 & 500 & 170 & 5 & 760 & 455 & 324 & $50 \%$ \\
\hline M75 & 500 & 170 & 5 & 760 & 228 & 486 & $75 \%$ \\
\hline
\end{tabular}

added and mixing continued for another $3 \mathrm{~min}$. After that, two-thirds of the water was added into the mix until the composite was well blended. The remaining water with superplasticizer was added into the mixer and mixing continued for another $5 \mathrm{~min}$ before conducting a slump test for determination of the workability of concrete.

The specimens were cast in steel moulds: $100 \mathrm{~mm}$ cubes for compressive strength, cylinders of $100 \mathrm{~mm}$ diameter $\times 200 \mathrm{~mm}$ height for splitting tensile strength, and cylinders of $150 \mathrm{~mm}$ diameter $\times 300 \mathrm{~mm}$ height for modulus of elasticity. During casting, all specimens were vibrated using a vibrating table for good compaction. For obtaining average values, all strengths were tested using at least three specimens.

Compressive strength and splitting tensile tests were conducted at 1, 3, 7, 28 and 56 days after casting. The modulus of elasticity tests was conducted at 28 days. A hydraulic press of $2000 \mathrm{kN}$ static loading capacity was conducted with the rate of $3 \mathrm{kN} / \mathrm{s}$ for compressive strength, $0.785 \mathrm{kN} / \mathrm{s}$ for splitting tensile strength and $4.418 \mathrm{kN} / \mathrm{s}$ for the modulus of elasticity. The modulus of elasticity was determined by the stress corresponding to $40 \%$ of the ultimate load and longitudinal strain.

\section{RESULTS AND DISCUSSION}

SLUMP

Table 3 shows the slump values of concrete mixes with different percentages of OPBC contents. As can be seen in this table, by increasing the OPBC in the concrete, the slump value decreases. The slump reduces significantly with a substitution of more than $25 \%$ OPBC. The reduction in the slump values is due to two reasons. First, the water absorption of the OPBC is much more than that of normal coarse aggregate (about six times). Second, OPBC aggregate is very porous on the surface unlike that seen visually on the surface of normal coarse aggregate. Such porosity absorbs the cement paste and hence reduces the workability of the concrete.

The trial mixes in this study showed that concrete containing $75 \%$ OPBC has very low workability. Adding superplasticizer does not affect the workability. In addition, bleeding is observed in the M75 concrete mix with more superplasticizer content. Therefore, OPBC could be used up to a level of $50 \%$.

It should be noted that with the same mix proportions, lightweight aggregate concrete has a lower slump value compared to normal weight aggregate concrete. However, it has been reported by Mehta and Monteiro (2006) that the workability of a lightweight aggregate concrete with a slump value of 50 to $75 \mathrm{~mm}$ is the same as that of conventional concrete with a slump value of 100 to $125 \mathrm{~mm}$.

Figure 1 shows the correlation between the concrete replacement with different percentages of OPBC coarse aggregate and slump value. A relation with a strong correlation for slump has been proposed. According to this figure, to obtain OPBC with acceptable workability (slump value of $50 \mathrm{~mm}$ ), the maximum substitution of OPBC concrete should be up to $65 \%$ if the OPBC is in dry condition.

\section{DENSITY}

Table 3 also shows four types of density for all mixes. As OPBC coarse aggregate is about $29 \%$ lighter than normal crushed granite, all types of density are reduced with a percentage increase in the substitution of OPBC. In

TABLE 3. Slump ( $\mathrm{mm})$ and density $\left(\mathrm{kg} / \mathrm{m}^{3}\right)$ of concrete mixes

\begin{tabular}{|c|c|c|c|c|c|}
\hline \multirow[b]{2}{*}{ Mix No. } & \multirow[b]{2}{*}{ Slump (mm) } & \multicolumn{4}{|c|}{ Density $\left(\mathrm{kg} / \mathrm{m}^{3}\right)$} \\
\hline & & Demoulded & $\begin{array}{c}\text { Air dry at } \\
28 \text { days }\end{array}$ & $\begin{array}{c}\text { Saturated at } \\
28 \text { days }\end{array}$ & $\begin{array}{c}\text { Oven dry at } \\
28 \text { days }\end{array}$ \\
\hline M & 160 & 2374 & 2349 & 2380 & 2308 \\
\hline M12.5 & 140 & 2353 & 2319 & 2360 & 2298 \\
\hline M25 & 130 & 2277 & 2271 & 2318 & 2242 \\
\hline M37.5 & 85 & 2275 & 2258 & 2299 & 2225 \\
\hline M50 & 75 & 2209 & 2207 & 2259 & 2202 \\
\hline M75 & 35 & 2181 & 2165 & 2200 & 2145 \\
\hline
\end{tabular}




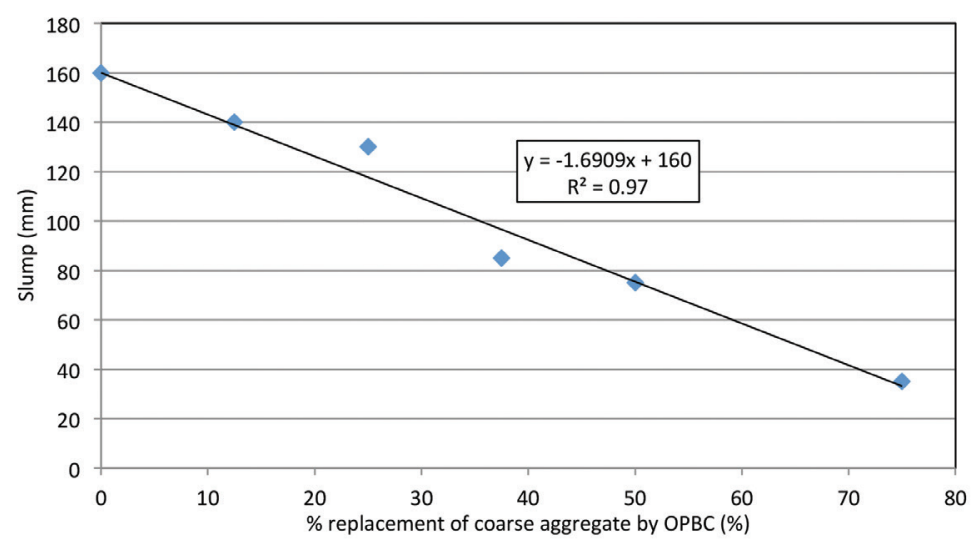

FIGURE 1. Relationship between slump and percentage replacement of coarse aggregate by OPBC

considering the oven dry density at 28 days, by increasing substitution of OPBC in normal weight concrete with a percentage of $12.5 \%$ to $75 \%$, the OPBC concrete is lighter than normal weight concrete by 0.4 to $7.1 \%$.

The oven dry density of lightweight concrete is defined by BS EN 206- 1 as being between 800 and $2000 \mathrm{~kg} / \mathrm{m}^{3}$ (BSI 1992). Therefore, the oven dry density in this study is not under the category of lightweight concrete. It has been reported that the density of normal weight concrete is in the range of $2240-2400 \mathrm{~kg} / \mathrm{m}^{3}$ while the density of lightweight concrete is $1440-1840 \mathrm{~kg} / \mathrm{m}^{3}$ (Nowak \& Rakoczy 2011 ). In general, the density of concrete not more than $2160 \mathrm{~kg} /$ $\mathrm{m}^{3}$ is considered to be lightweight concrete (Graybeal \& Lwin 2013). Therefore, the range of $1840-2240 \mathrm{~kg} / \mathrm{m}^{3}$ is considered to be semi-lightweight concrete (Adel et al. 2014). Among the four mixes containing OPBC aggregate, M50 mix can be considered as semi-lightweight concrete. This concrete includes $17 \%$ waste materials.

Figure 2 shows a linear relationship with a strong correlation between the oven dry density and percentage substitution of OPBC and oil palm shell (OPS) (Shafigh et al. 2012). Both OPBC and OPS are solid wastes from the palm oil industry. As a comparison with OPS concrete, it was noted that the oven dry density of OPBC concrete is much higher than that of OPS concrete. The reason being is that the specific gravity of OPBC is nearly twice that of OPS.

\section{COMPRESSIVE STRENGTHS}

The compressive strength of the full water cured concrete is shown in Table 4. From the test results, it was observed that the compressive strengths of all mixes increase with the increasing age of concrete. It can be observed that the use of $12.5 \%$ OPBC instead of normal weight coarse aggregate improves the compressive strength of control concrete; however, when the substitution percentage of OPBC increases, a reduction in the compressive strength in some ages is observed. However, the reduction for all substitution levels is not significant. Therefore, in general, it can be concluded that in a high strength normal weight concrete mixture, OPBC can be used up to $50 \%$ volume of coarse aggregate, as the concrete has satisfactory workability without a reduction in compressive strength. In particular, it is advised that in high strength concrete mixtures the minimum amount of OPBC aggregate used should be $12.5 \%$ of the total volume of coarse aggregate. The reason for having a good result for compressive strength was due to this aggregate having high surface porosity. Figure 3 shows the scanning electron microscopy image for surface texture of a grain of OPBC and normal crushed granite. It can be clearly observed that the surface of OPBC has greater porosity compared to that of crushed granite. Therefore, a part of the mixing water can be

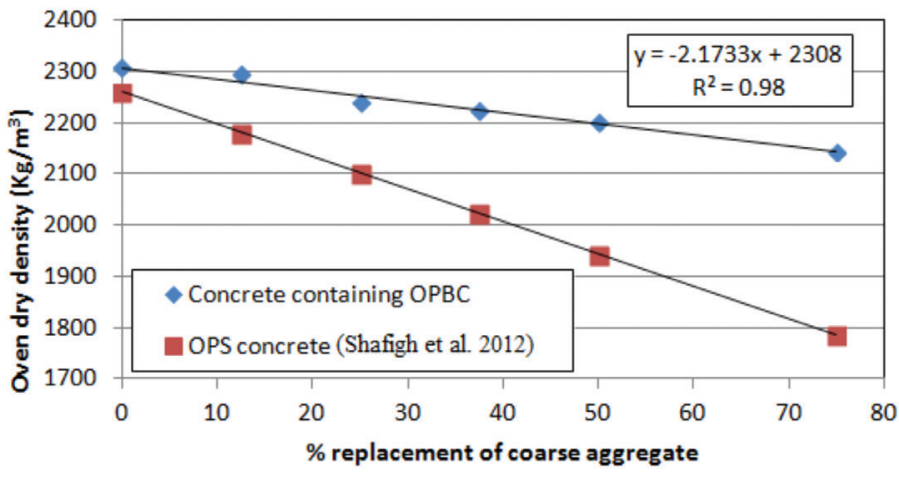

FIGURE 2. Relationship between density and percentage replacement of normal coarse aggregate by OPBC and OPS 
absorbed by aggregate and the effective water to cement ratio of the mixture is reduced. Hence, the compressive strength increases.

Concrete containing $50 \%$ OPBC is considered to be semi-lightweight concrete. However, the 28-day compressive strength of this concrete satisfies the requirement of high strength lightweight aggregate concrete (Holm 1994; Omar \& Mohamed 2002). The formation of high-strength concrete is very much dependent on density, strength and porosity of the structure using different types of lightweight aggregate (Zhang \& GjorvI 1990).

The test results showed that 7-day compressive strength of concrete containing OPBC is in the range of $90 \%$ to $95 \%$ that of 28-day compressive strength. It has been reported that concrete containing lightweight aggregate can achieve $80-92 \%$ of the 28-day compressive strength at 7-day age (Fujji et al. 1998; Omar \& Mohamed 2002). The 1-day and 3 -day compressive strength are $60 \%-75 \%$ and $78 \%-92 \%$ of their 28-day compressive strength. It is interesting to note that the rate of compressive strength gain of concrete containing OPBC at 56 days is more than for the control mix (an average of about $12.75 \%$ ). Therefore, it can be concluded that in high strength concrete, the mortar matrix plays a significant role in the compressive strength gain compared to the strength and quality of coarse aggregate.

\section{SPLITTING TENSILE STRENGTH}

Table 5 shows the splitting tensile strength test results for all the concrete mixes up to 56 days. It can be observed that partial contribution of OPBC as coarse aggregate in the concrete mixture reduced the splitting tensile strength, particularly at early ages. However, the reduction is not significant at later ages, 28 and 56 days. This performance of OPBC in splitting tensile strength is in contrast to the compressive strength. This shows that the substitution of normal weight coarse aggregate with a weaker aggregate has a negative effect on the splitting tensile strength but may increase the compressive strength.

Figure 4 shows a linear relationship with good correlation between the compressive and splitting tensile strength of concrete containing OPBC. Similar to the normal weight concrete, the splitting tensile strength increases as the compressive strength increases. However, the increasing rate of splitting tensile strength is much lower than that of the compressive strength (Zain et al. 2002).

TABLE 4. Compressive strength of concretes ${ }^{1}$

\begin{tabular}{lccccc}
\hline Mix No. & 1 day & 3 days & 7 days & 28 days & 56 days \\
\hline M & 53.8 & 56.2 & 68 & 71.7 & 77.7 \\
\multirow{3}{*}{ M12.5 } & $(75 \%)$ & $(78 \%)$ & $(95 \%)$ & & $(108 \%)$ \\
& 44.3 & 59.3 & 69 & 74.4 & 84.2 \\
M25 & $(60 \%)$ & $(80 \%)$ & $(93 \%)$ & & $(113 \%)$ \\
& 45.1 & 55.9 & 65.8 & 72.0 & 78.2 \\
M37.5 & $(63 \%)$ & $(78 \%)$ & $(91 \%)$ & & $(109 \%)$ \\
\multirow{2}{*}{ M50 } & 44.4 & 58.6 & 61.4 & 68.1 & 73.5 \\
& $(65 \%)$ & $(86 \%)$ & $(90 \%)$ & & $(108 \%)$ \\
& 48.8 & 61.2 & 64.9 & 68.1 & 75.8 \\
& $(72 \%)$ & $(90 \%)$ & $(95 \%)$ & & $(111 \%)$ \\
\hline
\end{tabular}

${ }^{1}$ The data in parentheses are percentages of the 28-day compressive strength
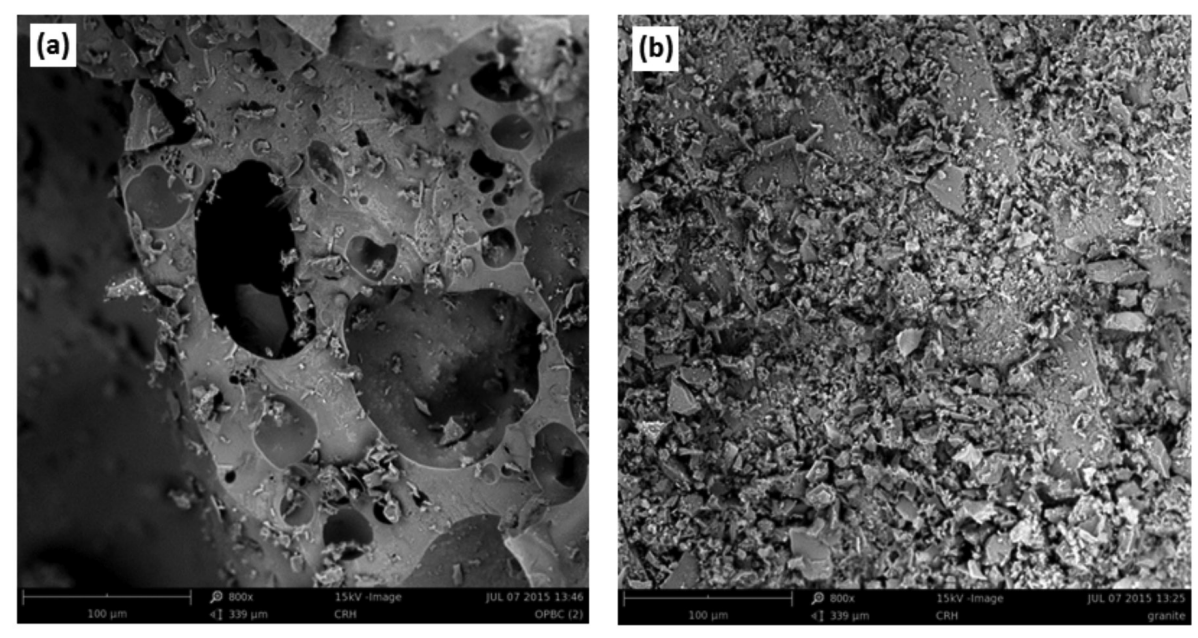

FIGURE 3. Scanning electron microscopy image for surface texture of (a) OPBC and (b) normal crushed granite 
Figure 4 also shows a comparison of concrete containing OPBC for predicting the splitting tensile strength from compressive strength, which can be derived from equation of CEP-PIP (1) (CEB-PIP 1993), pelletized blast furnace slag LWAC with cube compressive strength ranging of 10 to 65 MPa (2) (Neville 2008) and normal weight concrete with compressive strength ranging of 35-115 MPa (3) (Zain et al. 2002), as follows:

$$
\begin{aligned}
& f t=0.301 f_{c y}^{0.67}, \\
& f t=0.23 f_{c u}^{0.67}, \\
& f_{t}=f_{c y} /\left(0.1 f_{c y}+7.11\right) .
\end{aligned}
$$

where $f t$ is the splitting tensile strength $(\mathrm{MPa}) ; f_{c y}$ is the cylinder compressive strength (MPa) (a coefficient of 0.8 (Lo et al. 2004) was used to convert the cube to cylinder compressive strength); and $f_{c u}$ is the cube compressive strength (MPa).

It can be seen in this figure that (1) and (3) give a closer estimation to the experimental results, while (2) underestimates the values.

The 28-day measured ratio of splitting tensile/ compressive strength for OPBC concrete in this study is
$5.7-7.1 \%$. It has been reported by Kosmatka and Wilson (2011) that this ratio for normal weight concrete is around $8-14 \%$. The ratio in this study is lower than the normal weight concrete by $29-49 \%$. It also has been reported by Haque et al. (2004) that the splitting tensile strength to compressive strength ratio of LWAC is lower than that for normal weight concrete in the equivalent grade. In addition, the splitting tensile/compressive strength ratio of high strength lightweight concrete under continuously moist cured, also reached 6 - 7\% (Omar \& Mohamed 2002). The test results of this study showed that the ratio is the same as the value for high strength lightweight concrete.

\section{MODULUS OF ELASTICITY}

The modulus of elasticity of M, M12.5, M25, M37.5 and M50 mixes is $37.2,36.7,35.6,33.8$ and $32.5 \mathrm{GPa}$, respectively. Compared to the control mix $\mathrm{M}$, the substitution of coarse aggregate with $12.5 \%, 25 \%, 37.5 \%$ and $50 \%$ reduces the modulus of elasticity by about $1 \%$, $4 \%, 9 \%$ and $13 \%$, respectively. This is due to the modulus of lightweight density aggregate being less than that of normal density aggregate (Omar \& Mohamed 2002).

Compared to normal weight concrete, lightweight concrete has about a 25 - 50\% lower modulus of elasticity (Neville \& Brooks 2008). In general, the modulus of

TABLE 5. Splitting tensile strength under water curing

\begin{tabular}{lccccc}
\hline Mix No. & 1 day & 3 days & 7 days & 28 days & 56 days \\
\hline M & 3.69 & 3.86 & 4.31 & 4.96 & 5.21 \\
M12.5 & 3.11 & 3.78 & 4.08 & 4.95 & 5.22 \\
M25 & 3.06 & 3.76 & 4.19 & 4.37 & 4.71 \\
M37.5 & 3.02 & 3.46 & 3.5 & 4.84 & 4.54 \\
M50 & 3.35 & 3.67 & 3.62 & 4.86 & 4.75 \\
\hline
\end{tabular}

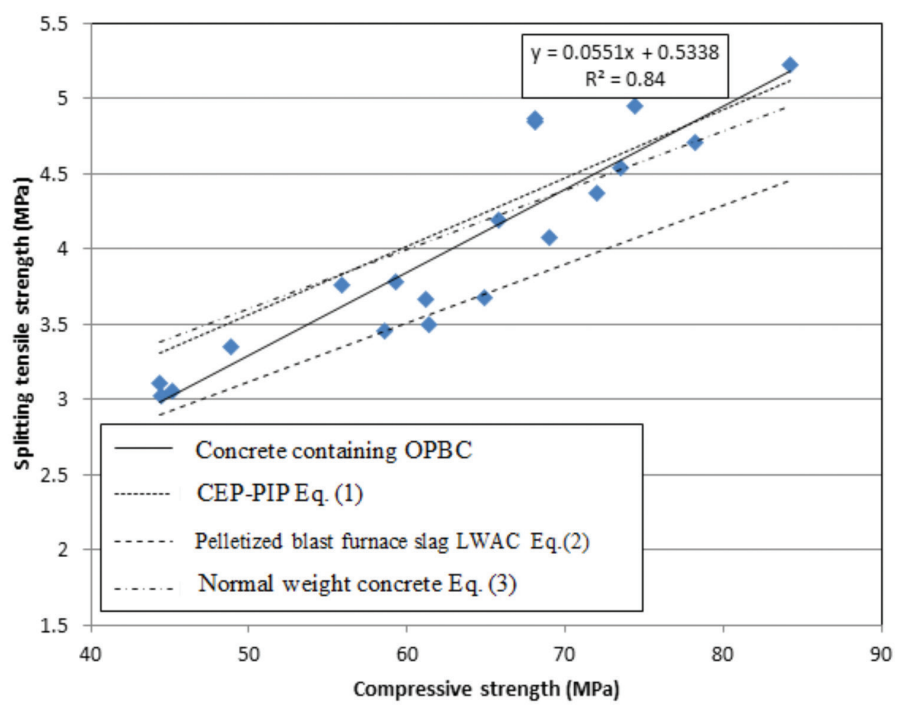

FIGURE 4. Relationship between compressive and splitting tensile strengths of concretes containing OPBC at 28-day age 
elasticity of structural lightweight concrete and normal weight concrete is in the range of 10 to $24 \mathrm{GPa}$ (CEB/ FIP 1977) and 14 to 41 GPa (Kosmatka \& Wilson 2011), respectively. Therefore, although up to $50 \%$ of normal weight coarse aggregate is replaced by OPBC lightweight aggregates, the modulus of elasticity of all the concrete mixes containing OPBC is in the range of normal weight concrete.

It is worth noting that the 28-day compressive strength and corresponding modulus of elasticity for all mixes show that at a low substitution level of granite with OPBC, the compressive strength increases, while the modulus of elasticity reduces slightly. In high substitution levels, the reduction in the compressive strength is slight, while the reduction in the modulus of elasticity is significant. As was mentioned earlier, although OPBC aggregate is weaker than granite aggregate (due to the porous nature of OPBC), its use did not affect the compressive strength test results. However, the modulus of elasticity is more affected by this substitution. This shows that the modulus of elasticity of concrete is significantly affected by the quality and modulus of elasticity of the aggregate rather than the quality and modulus of elasticity of the mortar.

Figure 5 shows a linear relationship with a strong correlation between the modulus of elasticity of the concrete and the percentage of replacement of normal weight coarse aggregate by OPBC and OPS. It is noted that there is a linear relationship with strong correlation between the modulus of elasticity and the percentage of replacement of OPBC with normal coarse aggregate with the best fit equation of $\mathrm{E}=-0.2341 \mathrm{k}+1$, where $\mathrm{E}$ and $\mathrm{k}$ are the of elasticity $(\mathrm{GPa})$ and the percentage of replacement of $\mathrm{OPBC}$, respectively. The modulus of elasticity of concrete containing OPBC is much higher than that of OPS concrete. This is due to the density of OPBC grain being much higher than that of the OPS shells.

Figure 6 shows the relationship between the modulus of elasticity and compressive strength for all mixes. It can be seen that a parabolic correlation gives $\mathrm{E}=0.0284$ with $\mathrm{R}^{2}$ of 0.92 ; where E and are modulus of elasticity (GPa) and cube compressive strength (MPa), respectively. Figure 6 also shows a comparison of the concrete containing OPBC in this study for predicting modulus of elasticity from the compressive strength derived from equation by BS8110 (1985) (4) and Tasnimi (2004) (5) who reported data for artificial LWAC with cylinder compressive strength ranging from 15-55 $\mathrm{MPa}$, as shown below:

$$
\begin{aligned}
& E=0.0017 w^{2} f_{c u}^{0.33}, \\
& E=2.168 f_{c y}^{0.535},
\end{aligned}
$$

where is the modulus of elasticity $(\mathrm{MPa})$ and $(\mathrm{GPa})$ for (4) and (5), respectively, is the air dry density $\left(\mathrm{kg} / \mathrm{m}^{3}\right)$, is the cylinder compressive strength (MPa) (a coefficient of 0.8 (Lo et al. 2004) is used to convert the cube to cylinder compressive strength) and is the cube compressive strength (MPa).

As can be seen in Figure 6, (4) provides a better estimate of the value for this study while (5) underestimates the values.

\section{CONCLUSION}

In this study, normal coarse aggregate in a grade 70 high strength concrete was substituted with $25 \%, 50 \%$ and $75 \%$ of OPBC by volume. The effect of this substitution on fresh and hardened properties of the concrete was considered. Based on test results of this experimental work the following conclusion can be drawn. The slump value decreases by increasing the OPBC coarse aggregate in normal weight concrete. Based on the correlation between slump and OРВC content, it was found that $65 \%$ substitution of OPBC (in dry condition) is optimum to provide satisfactory workability for OPBC concrete. Increasing the volume of OPBC in concrete leads to a reduction in density of concrete. However, the density of concrete containing up to $37.5 \%$ OPBC is in the range of normal weight concrete while at $50 \%$ substitution, the level of concrete can be considered as semi-lightweight

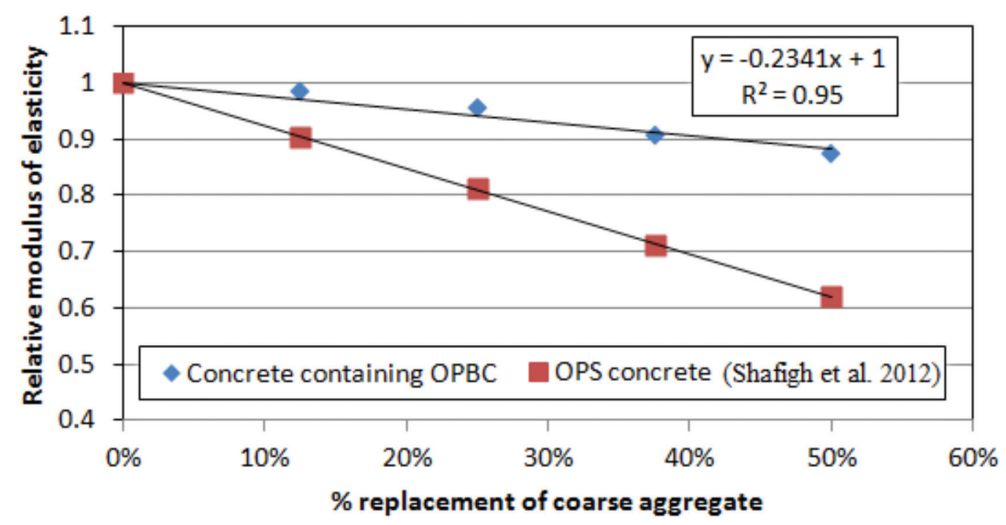

FIGURE 5. Relationship between relative modulus of elasticity and percentage replacement of normal coarse aggregate with OPBC and OPS 


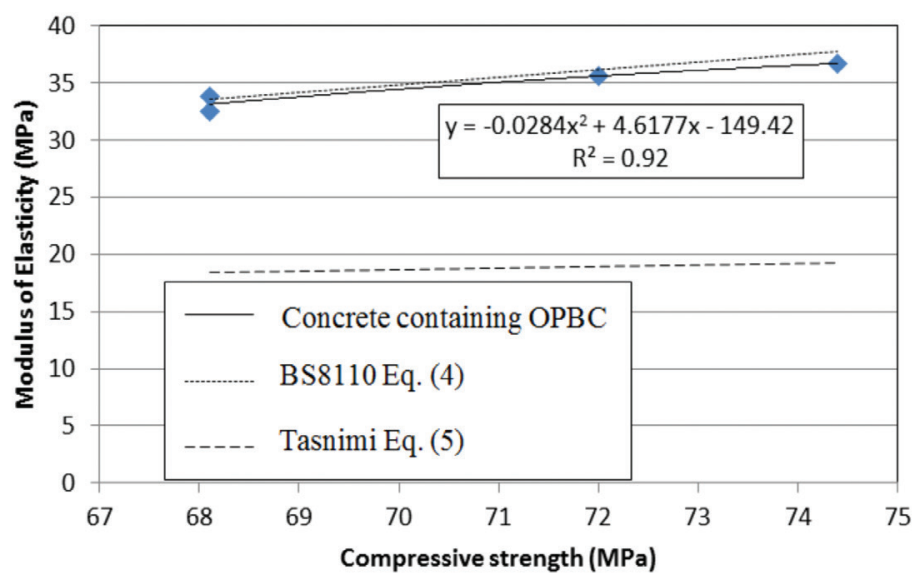

FIGURE 6. Relationship between modulus of elasticity and compressive strength of concrete containing OPBC at 28-day

concrete. Concrete containing $12.5 \%$ OPBC had the highest compressive strength compared to the other concrete mixes. However, tensile strength and modulus of elasticity of this concrete were equivalent to the control mix. Therefore, due to the benefits of using $12.5 \%$ OPBC in concrete mixture in both cases of mechanical properties and environmental aspect, it is strongly recommended that at least $12.5 \%$ of normal weight coarse aggregate is replaced with OPBC in high strength concretes. Incorporating $\mathrm{OPBC}$ in normal weight concrete reduces the splitting tensile strength. The modulus of elasticity reduces when normal coarse aggregate is replaced by OPBC aggregate. However, the reduction in the modulus of elasticity is not significant for concrete containing $37.5 \%$ OPBC.

\section{ACKNOWLEDGEMENTS}

The authors gratefully acknowledge the financial support from University of Malaya under the University Malaya Research Fund Assistance (BKP), Grant No. BK055-2014.

\section{REFERENCES}

Adel, G.K., Payam, S., Mahmoud, M. \& Hilmi, B.M. 2014. The role of 0-2 $\mathrm{mm}$ fine recycled concrete aggregate on the compressive strength and splitting tensile strength of recycled concrete aggregate concrete. Materials and Design 64: 345-354.

Ahmad, M.H. \& Mohd, S. 2007. Mechanical Properties Of Palm Oil Clinker Concrete, (December).

BSI Document 92/17688. 1992. European Draft Standard Specification for lightweight aggregates, CEN/TC154/SC5, Sub Committee Lightweight Aggregates.

BS 8110: Part 2:1985. Structural use of concrete. Part 2: Code of practice for special circumstances. London: British Standards Institution.

Caldarone, M.A. 2009. High-strength concrete - a practical guide. Canada: Taylor \& Francis.

CEB/FIP. 1977. Manual of Design and Technology, Lightweight Aggregate Concrete. 1st ed. Lancaster: The Construction Press Ltd.
Chin, K.L. 2005. Major Challenges in Protecting Biodiversity. New Straits Times. January 25.

Committee Euro-International du Beton (CEB-PIP). 1993. CEBPIP Model Code 1990. London: Thomas Telford.

Construction Industry Development Board (CIDB) 2000. Malaysian Construction Industry: Technology Foresight Report. CIDB Malaysia and APEC Technology Foresight Center, Bangkok.

Construction Industry Development Board (CIDB) 2007. Strategic Recommendations for Improving Environmental Practices in Construction Industry. Kuala Lumpur: CIDB Publisher.

Fujji, K., Adachi, S., Takeuchi, M.T., Kakizaki, M., Edahiro, H., lnoue, T. \& Yamamoto, Y. 1998. Properties of high-strength and high-fluidity lightweight concrete. ACI Spec. Publ. 179: 65-84.

Graybeal, B. \& Lwin, M.M. 2013. Lightweight concrete in highway infrastructure. ASPIRE. pp. 44-45.

Haque, M.N., Al-Khaiat, H. \& Kayali, O. 2004. Strength and durability of lightweight concrete. Cem. Concr. Compos. 26: 307-314.

Holm, T.A. 1994. Lightweight Concrete and Aggregates. ASTM Stand. Tech. Publ. 169C. pp. 522-532.

Kanadasan, J. \& Abdul Razak, H. 2015. Engineering and sustainability performance of self-compacting palm oil mill incinerated waste concrete. Journal of Cleaner Production 89: 78-86.

Kosmatka, S.H. \& Wilson, M.L. 2011. Design and Control of Concrete Mixtures, EB001, fifteenth ed. Portland Cement Association, Skokie, Illinois, USA.

Lo, T.Y., Cui, H.Z. \& Li, Z.G. 2004. Influence of aggregate prewetting and fly ash on mechanical properties of lightweight concrete. Waste Manage. 24: 333-338.

Mannan, M.A. \& Ganapathy, C. 2004. Concrete from an agricultural waste-oil palm shell (OPS). Build Environ. 39(4): 441-448.

Mannan, M.A. \& Ganapathy, C. 2002. Engineering properties of concrete with oil palm shell as coarse aggregate. Constr. Build Mater. 16(1): 29-34.

Mehta, P.K.\& Monteiro, P.J.M. 2006. Concrete: Microstructure, Properties and Materials. 3rd. ed. New York: McGraw-Hill.

Mohammed, B., Al-Ganad, M.A. \& Abdullahi, M. 2011. Analytical and experimental studies on composite slabs 
utilising palm oil clinker concrete. Construction and Building Materials 25: 3550-3560.

Neville, A.M. \& Brooks, J.J. 2008. Concrete Technology. New Delhi: Pearson Education Asia Pte Ltd, PP(CTP).

Neville, A.M. 2008. Properties of Concrete. 14th ed. Malaysia: CTP-WP.

Nowak,A.\& Rakoczy,A. 2011. Statistical model for compressive strength of lightweight concrete. Architect Civ. Eng. Environ. 4(4): 73-80.

Omain, S.Z., Hamid, A.B.A., Rahim, A.R.A. \& Salleh, N.M. 2010. Supply chain management practices in Malaysia palm oil industry. In The 11th Asia Pacific Industrial Engineering and Management Systems Conference, Melaka, Malaysia, 7-10 December.

Omar, W. \& Mohamed, R.N. 2002. The performance of pretensioned prestressed concrete beams made with lightweight concrete. J. Civ. Eng. 14(1): 60-70.

Shafigh, P., Jumaat, M.Z. \& Mahmud, H.B. 2012. Effect of replacement of normal weight coarse aggregate with oil palm shell on properties of concrete. Arab J. Sci. Eng. DOI 10.1007/s13369-012-0233-2.

Tasnimi, A.A. 2004. Mathematical model for complete stressstrain curve prediction of normal, light-weight and highstrength concretes. Mag. Con. Res. 56(1): 23-34.

Wahid, M.B. 2005. Malaysian Palm Oil Board (MPOB): Overview of the Malaysian Oil Palm Industry 2005. http:// econ.mpob.gov.my/ economy/su_review 2005.htm. Accessed on 14 February 2013.

Wong K.K. 2012. Concrete Waste: Discard or Recycle? Borneo Post. http://www.theborneopost.com/2012/10/31/concretewaste-discard-or-recycle/. Accessed on 14 February 2013.

Zain, M.F.M., Mahmud, H.B., Ilham, A. \& Faizal, M. 2002. Prediction of splitting tensile strength of high-performance concrete. Cem. Concr. Res. 32(8): 1251-1258.

Zhang, M.H. \& GjorvI, O.E. 1990. Development of high-strength lightweight concrete. ACI Spec Publ. 121: 667-682.
Lee Jin Chai, Hilmi Bin Mahmud \& Muhammad Aslam Department of Civil Engineering

Faculty of Engineering, University of Malaya

50603 Kuala Lumpur, Federal Territory

Malaysia

Lee Jin Chai

Department of Civil Engineering

Faculty of Engineering, UCSI University

Cheras 56000, Kuala Lumpur, Federal Territory

Malaysia

Payam Shafigh*

Department of Building Surveying

Faculty of Built Environment, University of Malaya

50603 Kuala Lumpur, Federal Territory

Malaysia

Payam Shafigh*

Center for Building, Construction \& Tropical Architecture (BuCTA)

Faculty of Built Environment

University of Malaya

50603 Kuala Lumpur

Malaysia

*Corresponding author; email: pshafigh@gmail.com

Received: 5 January 2016

Accepted: 6 September 2016 